Part 5: Typology performance study 


\title{
Seismic behaviour assessment of vernacular isolated buildings
}

\author{
J. Ortega, G. Vasconcelos \& P.B. Lourenço \\ ISISE, Faculty of Engineering, University of Minho, Guimarães, Portugal \\ H. Rodrigues \\ School of Technology and Management, Polytechnic Institute of Leiria, Portugal \\ H. Varum \\ CONSTRUCT-LESE, Faculty of Engineering, University of Porto, Portugal
}

\begin{abstract}
This paper presents the numerical seismic analysis of isolated vernacular buildings characteristic of the Alentejo region, which is considered a medium seismic hazard region in Portugal. A representative isolated building was selected from a database, and a geometric model was defined for the numerical pushover analysis. Subsequently, a parametric analysis was carried out to assess the influence of distinct parameters on the seismic behaviour of such buildings.
\end{abstract}

\section{INTRODUCTION}

The reasons behind the selection of the different vernacular building typologies, in order to assess their seismic performance are: (i) firstly, the buildings should represent typologies that can be encountered in regions that were previously identified as prone to have developed a Local Seismic Culture, i.e., where the seismicity is high, and earthquakes are frequent, even if of low intensity; (ii) secondly, traditional seismic strengthening solutions should have been already identified in some of the buildings belonging to the typology, revealing the possible existence of a Local Seismic Culture.

Additionally, in order to make the study more comprehensive, it was deemed necessary to include differentiated vernacular typologies in both, urban and rural contexts. Vernacular architecture in Portuguese rural environments, in contrast with urban vernacular constructions, usually consists of independent buildings of small dimensions, with no structural interaction between them. Therefore, the case study analysed herein involves isolated vernacular buildings.

\section{SELECTION OF A CASE STUDY}

The first vernacular building typology chosen as a case study consists of a representative vernacular rammed earth construction, commonly found in the South Portuguese region of Alentejo, where the seismicity is high in relation to other Portuguese regions, and is thus prone to have developed a Local Seismic Culture. Rammed earth construction, known as taipa in
Portugal, essentially consists of the compacting of the earth using a timber formwork for the construction of free standing walls. This has traditionally been the most widespread technique in these regions and, even though its use decreased significantly in the last forty years, is still in use in some places.

Traditional dwellings in Alentejo have generally small dimensions, simple rectangular shape and only one floor, having predominant horizontal dimensions. They were also very simple, regarding their plan configuration, little compartmentalised, and using rammed earth walls also for the partition walls. They present massive shapes, with few or no openings, other than a single door, as a protection for the hot summers. Chimneys are the only relevant protruding non-structural element that can be systematically found in this type of buildings. Other materials are also used, such as stone or brick masonry, in order to reinforce the corners, and to build a base course or soco. This aims at protecting the rammed earth from the humidity and rain penetration, by preventing the action of rising damp, but it also helps reinforcing the rammed earth walls. Roofs are commonly monopitched roofs or gable roofs, usually presenting a low slope, and made with a simple framework of timber beams. Buildings were finally painted in white, in order to reflect the sunlight.

Satisfying the second important requirement to be chosen as a case study, traditional seismic strengthening solutions could be identified in several of these characteristic rammed earth constructions (Correia 2005, Correia 2007). Mainly, buttresses, known as gigantes in the region, could be usually observed attached to the exterior walls (Fig. 1). They perform an 


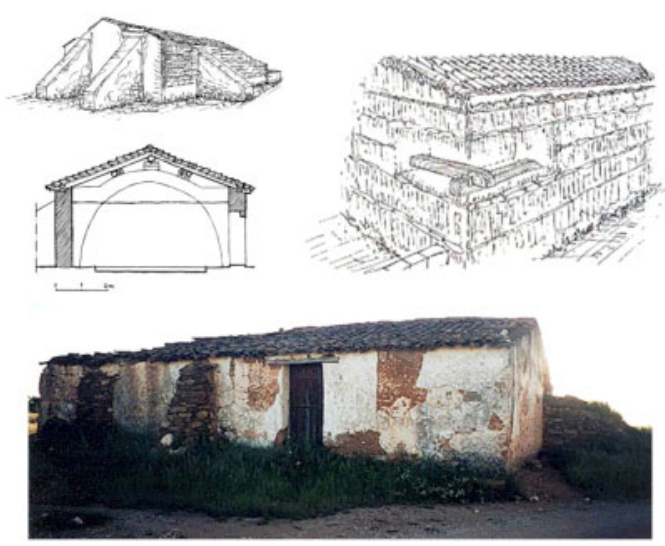

Figure 1. Traditional seismic strengthening solutions identified in rammed earth constructions of Alentejo (credits: Correia, 2007).

important task in the event of an earthquake, counteracting the horizontal forces exerted by the buildings. Their efficiency might be determined by their relative position within the building. Ties are also very commonly found in this type of buildings (Fig. 1), performing another important task by coupling the structural elements, such as parallel walls, and contributing to the achievement of a box-behaviour of the structure. Other traditional strengthening solutions observed consist in the introduction of timber elements to reinforce the connections of the walls at the corners (Fig. 1). Timber lintels and discharging arches over the openings are also among the reinforcing techniques observed.

\section{STRUCTURAL ANALYSIS OF ISOLATED BUILDINGS}

The study of the seismic behaviour of ancient constructions built with traditional materials is particularly challenging, given the multiple uncertainties regarding the material properties, connections between structural and non-structural elements, or even the uncertainties about the state of conservation of the construction. Rammed earth constructions are composed by generally thick load bearing walls, whose in-plane resistance is significantly higher, than its out-of-plane resistance. These thick walls can exhibit substantial structural ductility and deformations, larger than the expected for such a brittle material (Michiels 2014). This behaviour is associated with a highly nonlinearity, which complicate the structural analysis and safety assessment of these structures, particularly when submitted to seismic loading.

Aiming at having a better insight of the seismic behaviour of the traditional rammed earth construction found in Alentejo region, a numerical analysis was carried out based on representative building for the assessment of the seismic behaviour.

\subsection{Finite element model}

The Finite Element Modelling (FEM) is used for the global seismic analysis of a rammed earth vernacular building, following a common macro-model approach, which has already been extensively and successfully applied with the aim of analysing the seismic behaviour of complex masonry structures (Lourenço et al. 2011). However, in order to understand and accurately simulate the seismic behaviour of rammed earth constructions, it is important to describe accurately the nonlinear behaviour through advanced plastic constitutive models, since relevant deformation of the structural elements is expected. Few studies have focused on the finite element modelling of rammed earth buildings (Bui et al. 2008, Jaquin 2008, Braga \& Estêvão 2010, Gomes et al. 2011, Angulo-Ibáñez et al. 2012, Gallego \& Arto 2014, Miccoli et al. 2014), and most of them have adopted simple models, assuming simple constitutive laws, mainly linear elastic isotropic. Therefore, finite element modelling, based on nonlinear numerical analysis of rammed earth vernacular buildings represents a step forward in technical and scientific knowledge, as few results are available in literature.

This numerical simulation intends to understand, in a more detailed way, the resisting mechanisms of the different structural elements of this typology under seismic loading, based on nonlinear static (pushover) analyses. Pushover analysis has been already commonly used for the seismic assessment of existing masonry buildings (Lourenço et al. 2011), and mainly consists of simulating the seismic loading as static horizontal forces, which are applied incrementally on the structure. It allows determining the ability of the building to resist the characteristic horizontal loading caused by the seismic actions, taking into account the material nonlinear behaviour, while being simpler than other methods of analysis, like nonlinear dynamic analysis and, therefore, it was chosen for this study.

\subsubsection{Reference building geometry}

From the analysis of the buildings of the database found in the literature previously mentioned (Correia 2007), a reference model was built, which intends to be a simplified representative example of these constructions, gathering common characteristics in terms of dimensions and architectural layout. The reference building geometry was based on a specific example located in Vila Nova de São Bento, in the Beja district, in Alentejo (Fig. 2). However, some changes were adopted in the geometry and construction details, in order to typify more precisely the rest of the buildings belonging to this typology. The final plan and elevation views of the reference building used are shown in figure 3 . The plan has a simple rectangular shape, symmetrical in both orthogonal directions, regarding also the distribution of the interior load bearing walls. The height of this type of buildings rarely surpasses 3 meters at the front and back walls. The gable walls are not very high either, keeping the roof slope low, between 15-20 degrees. 

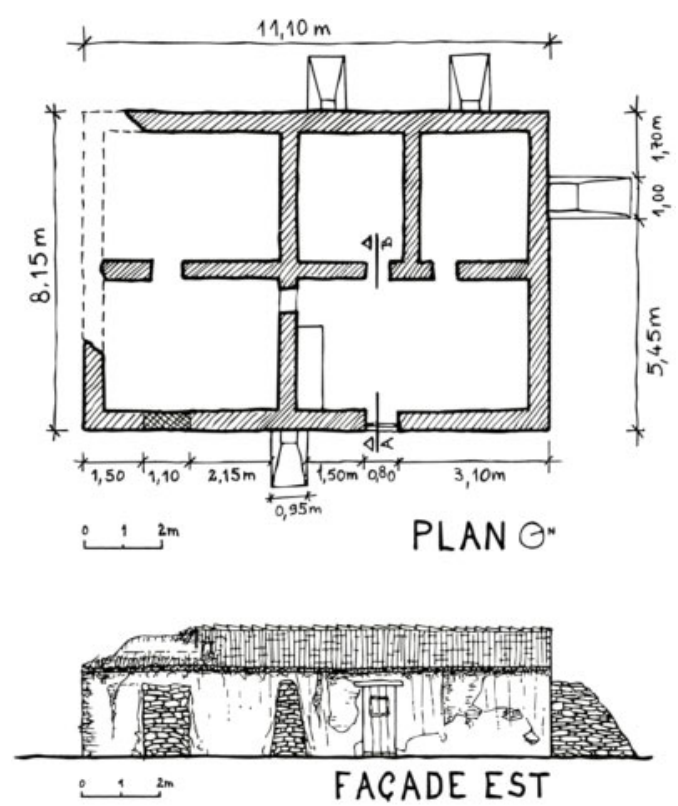

Figure 2. Original rammed earth building in Vila Nova de São Bento, in the Beja district, in Alentejo (credits: Correia, 2007).

The height of the stone masonry course at the base is very variable, but it was established as 0.4 meters. Regarding the openings, the position of the two doors and two windows have also a symmetrical configuration.

Timber lintels were considered over the openings, as this is also the common practice observed in almost every building of the database. Chimneys or other nonstructural elements were not added to the reference building at this initial step.

\subsubsection{Reference numerical model}

The final reference numerical model was built based on the previously commented characteristics, using DIANA software (TNO 2009). Three different materials are considered. Stone masonry is used for the base course, which is usually built with irregular schist, or granite masonry and thus, poor material properties are assumed. Rammed earth is used for the structural walls, both interior and exterior. Timber is used for the lintels over all the openings. The roof is only considered as a distributed load on the top of the walls, and the displacements of the elements at the base are fully restrained.

The material model finally adopted to represent the nonlinear behaviour of the rammed earth and stone masonry, which are the two materials considered to present nonlinear behaviour; it is a standard isotropic Total Strain Rotating Crack Model (TSRCM), which describes the tensile and compressive behaviour of the material with one stress-strain relationship, and assumes that the crack direction rotates with the principal strain axes. An isotropic model was chosen,
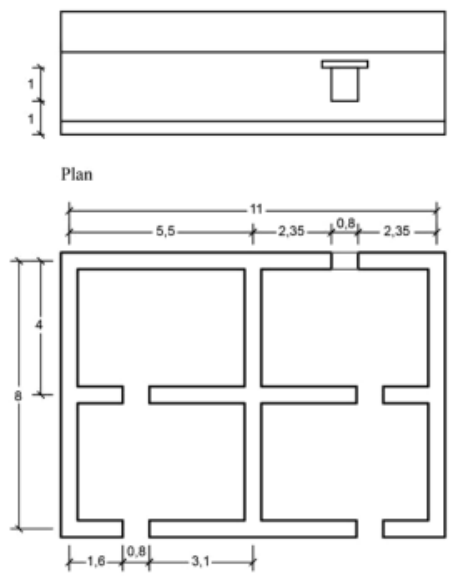

Elevation 2
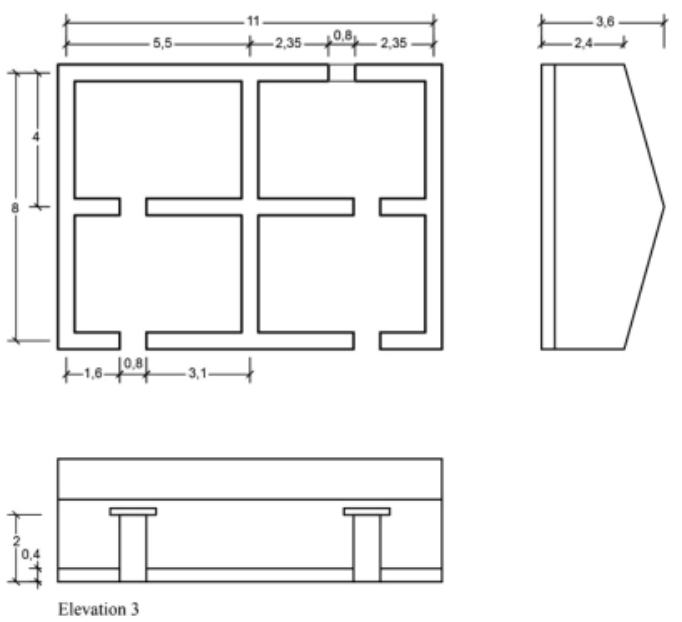

Figure 3. Plan and elevations of the reference building adopted for the construction of the numerical model (credits: J. Ortega).

because despite its layered structure, experimental tests found in the literature have shown that the mechanical properties of rammed earth do not behave in an anisotropic way (Miccoli et al. 2014). This model is very well suited for analyses, which are predominantly governed by cracking or crushing of the material. The tension softening function selected is exponential, and the compressive function selected to model the crushing behaviour is parabolic. The detailed information required for the rammed earth material properties were obtained from data collected, from different authors, and it is shown in Table 1. It is noted that there is a big variability, bringing up even more uncertainties. For the timber lintels, only the elastic properties are considered, and an elasticity modulus of $10 \mathrm{GPa}$, and a Poisson's ratio of 0.2 were used (Gomes et al. 2011). Regarding the stone masonry elastic properties, a modulus of elasticity of $1500 \mathrm{MPa}$, and a Poisson's ratio of 0.2 were adopted. Its compressive strength and specific weight were obtained from reference values, given by the Italian code (NTC08 2009), assuming the lowest quality masonry class, an irregular rubble stone masonry composed of rubble and irregular stone units of different sizes and shapes. The remaining nonlinear properties of the masonry were computed directly from the compressive strength, based on recommendations given by Lourenço (2009). The compressive fracture energy was obtained, using a ductility factor of $1.6 \mathrm{~mm}$, which is the ratio between the fracture energy and the ultimate compressive strength. 
Table 1. Rammed earth material properties used for the finite element model found in the literature.

\begin{tabular}{llllll}
\hline Author & $\begin{array}{l}\mathrm{W} \\
\left(\mathrm{kN} / \mathrm{m}^{3}\right)\end{array}$ & $\begin{array}{l}\mathrm{f}_{\mathrm{c}} \\
(\mathrm{MPa})\end{array}$ & $\begin{array}{l}\mathrm{f}_{\mathrm{t}} \\
(\mathrm{MPa})\end{array}$ & $\begin{array}{l}\mathrm{E} \\
(\mathrm{MPa})\end{array}$ & $v$ \\
\hline $\begin{array}{l}\text { Jaquin (2008) } \\
\text { Bui et al. } \\
(2008)\end{array}$ & - & $0.60-0.70$ & - & 60 & - \\
$\begin{array}{l}\text { Braga \& } \\
\text { Estêvão (2010) }\end{array}$ & 20 & 0.89 & 0.17 & 264 & - \\
$\begin{array}{l}\text { Gomes et al. } \\
(2011)\end{array}$ & 19 & 0.67 & - & 200 & 0.35 \\
$\begin{array}{l}\text { Angulo-Ibáñez } \\
\text { et al. (2012) }\end{array}$ & 20 & - & - & 500 & 0.2 \\
$\begin{array}{l}\text { Gallego \& } \\
\text { Arto (2014) }\end{array}$ & 20 & 1.85 & 0.29 & 250 & - \\
$\begin{array}{l}\text { Miccoli et al. } \\
(2014)\end{array}$ & - & 3.7 & 0.37 & 4207 & 0.27 \\
\hline
\end{tabular}

Table 2. Mechanical elastic properties adopted for the three materials used in the reference model.

\begin{tabular}{|c|c|c|c|}
\hline Material & $\begin{array}{l}\mathrm{E} \\
(\mathrm{MPa})\end{array}$ & $v$ & $\begin{array}{l}\mathrm{W} \\
\left(\mathrm{kN} / \mathrm{m}^{3}\right)\end{array}$ \\
\hline Stone masonry & 1500 & 0.2 & 20 \\
\hline Rammed earth & 300 & 0.3 & 20 \\
\hline Timber & 10000 & 0.2 & 6 \\
\hline
\end{tabular}

Table 3. Mechanical nonlinear properties adopted for the materials used in the reference model.

\begin{tabular}{llllll}
\hline Material & $\begin{array}{l}\mathrm{f}_{\mathrm{c}} \\
(\mathrm{MPa})\end{array}$ & $\begin{array}{l}\mathrm{G}_{\mathrm{fc}} \\
(\mathrm{MPa})\end{array}$ & $\begin{array}{l}\mathrm{f}_{\mathrm{t}} \\
(\mathrm{MPa})\end{array}$ & $\begin{array}{l}\mathrm{G}_{\mathrm{fI}} \\
(\mathrm{N} / \mathrm{mm})\end{array}$ & $\beta$ \\
\hline Stone masonry & 1.5 & 2.4 & 0.15 & 0.012 & 0.05 \\
Rammed earth & 1 & 1.6 & 0.1 & 0.1 & 0.05 \\
\hline
\end{tabular}

The tensile strength was estimated at $1 / 10$ of the compressive strength. Finally, an average value of $0.012 \mathrm{~N} / \mathrm{mm}$ is adopted for the mode I fracture energy. Concerning the rammed earth material elastic properties, an elasticity modulus of $300 \mathrm{MPa}$ and a Poisson's ratio of 0.3 were used. A compressive strength of $1 \mathrm{MPa}$ was adopted. The remaining nonlinear properties were again calculated directly from the compressive strength, following the same recommendations (Lourenço, 2009). The unique difference with respect to the stone masonry lies in the value used for the mode I fracture energy. According to Miccoli et al. (2014), the fracture energy of rammed earth should be obtained by increasing the compressive strength about ten times, as it is considered that rammed earth behaves in a different way, in comparison with stone masonry, which behaves as a brittle material. Due to its broad particle size distribution, which includes large particles that may have a significant contribution for the interlocking at the crack surface, by promoting its roughness, a value of $0.1 \mathrm{~N} / \mathrm{mm}$ was adopted for the fracture energy

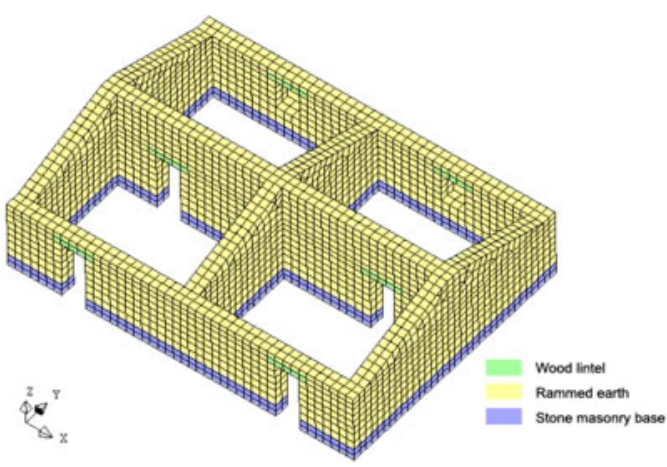

Figure 4. Numerical model: Mesh categorized by materials (credits: J. Ortega).

of rammed earth. Tables 2 and 3 present the material properties used for the analyses.

The model is built with solid 3D elements: (i) twenty-node isoparametric solid brick elements (CHX60), with three-by-three Gauss integration in the volume; and (ii) fifteen-node isoparametric solid wedge elements (CTP45), with a four-point integration scheme in the triangular domain, and a three-point scheme in the orthogonal direction, used to adjust the mesh to the geometry resulting from the triangular gable walls. The final reference model has two elements in the thickness direction of the wall and therefore, the resulting generated mesh has 31,264 nodes and 7,993 elements (Fig. 4). The total mass of the model is 150 tons.

\section{SEISMIC PERFORMANCE OF THE CASE STUDY}

As a first step, the main dynamic characteristics of the reference model are obtained and summarised in Table 4. Results show that the mass participation of the first modes is low, in comparison with common modern RC buildings with rigid floors, since the accumulated mass participation of the first 20 modes is around $45 \%$ and $65 \%$ in $\mathrm{X}$ and $\mathrm{Y}$ direction, respectively. Most of the modes are associated with local deformations, involving only specific structural elements at a time, and there is no global modes affecting the whole structure. This effect is derived from the fact that there is no rigid floor coupling the vertical structural elements, and the roof is not modelled. Thus, the walls get to vibrate independently. The first modes are associated with local out-of-plane deformations of the walls in the $\mathrm{Y}$ direction, particularly the taller inner walls, less resistant to local deformations. The sixth mode is the first one showing relevant displacements in the $\mathrm{X}$ direction. Figure 5 shows the shape of the first, third and sixth mode.

A nonlinear static (pushover) analysis was then carried out. First, only the dead weight and the distributed load on top of the walls, simulating the roof, are considered. After that, an incremental monotonic loading, 
Table 4. Results from the dynamic analysis.

\begin{tabular}{|c|c|c|c|c|c|}
\hline \multirow[b]{2}{*}{ Mode } & \multirow{2}{*}{$\begin{array}{l}\text { Period } \\
\text { (s) }\end{array}$} & \multirow{2}{*}{$\begin{array}{l}\text { Frequency } \\
(\mathrm{Hz})\end{array}$} & \multicolumn{3}{|c|}{ Mass participation* } \\
\hline & & & $\mathrm{U}_{x}$ & $\mathrm{U}_{y}$ & $\mathrm{U}_{z}$ \\
\hline 1 & 0.150 & 6.66 & $\begin{array}{l}0.00 \\
(0.00)\end{array}$ & $\begin{array}{l}0.00 \\
(0.00)\end{array}$ & $\begin{array}{l}0.00 \\
(0.00)\end{array}$ \\
\hline 2 & 0.134 & 7.45 & $\begin{array}{l}0.00 \\
(0.00)\end{array}$ & $\begin{array}{l}11.18 \\
(11.18)\end{array}$ & $\begin{array}{l}0.00 \\
(0.00)\end{array}$ \\
\hline 3 & 0.099 & 10.13 & $\begin{array}{l}0.39 \\
(0.39)\end{array}$ & $\begin{array}{l}0.00 \\
(11.18)\end{array}$ & $\begin{array}{l}0.00 \\
(0.00)\end{array}$ \\
\hline 5 & 0.096 & 10.38 & $\begin{array}{l}0.00 \\
(2.56)\end{array}$ & $\begin{array}{l}0.00 \\
(11.18)\end{array}$ & $\begin{array}{l}0.00 \\
(0.00)\end{array}$ \\
\hline 10 & 0.08 & 12.58 & $\begin{array}{l}0.00 \\
(40.76)\end{array}$ & $\begin{array}{l}3.16 \\
(31.73)\end{array}$ & $\begin{array}{l}0.01 \\
(0.02)\end{array}$ \\
\hline 20 & 0.05 & 19.98 & $\begin{array}{l}0.00 \\
(43.98)\end{array}$ & $\begin{array}{l}17.13 \\
(63.59)\end{array}$ & $\begin{array}{l}0.01 \\
(0.06)\end{array}$ \\
\hline
\end{tabular}

*Accumulated mass participation in brackets.
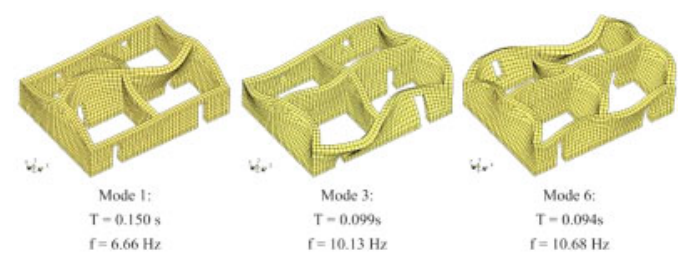

Figure 5. Shape of the first, third and sixth mode of the reference building (credits: J. Ortega).

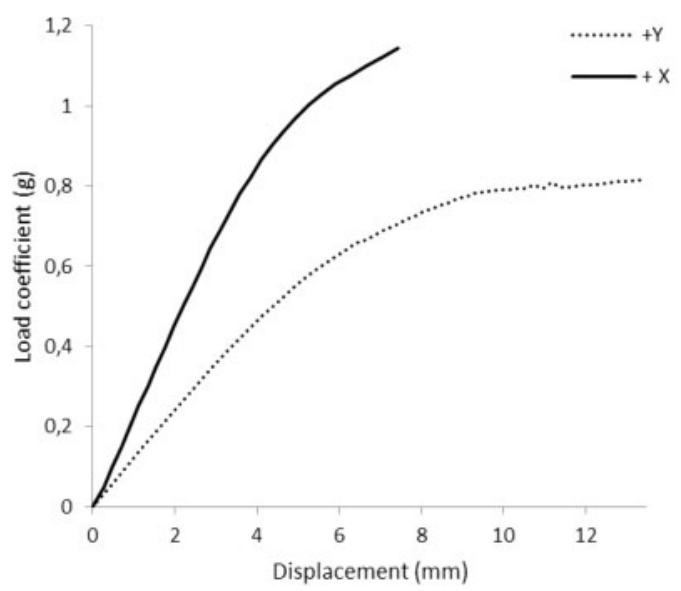

Figure 6. Capacity curve of the pushover analysis on the reference building in $+\mathrm{X}$ and $+\mathrm{Y}$ direction (credits: $\mathrm{J}$. Ortega).

proportional to the mass, is applied on the structure in the main horizontal directions ( $\mathrm{X}$ and $\mathrm{Y}$ ), as recommended by Lourenço et al. (2011) for masonry structures. Given the local modes previously observed in the modal identification, a modal pushover analysis was disregarded. Only the positive directions are considered, since the behaviour of the building is practically symmetric.

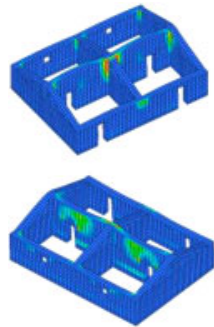

(a) $0.346 \mathrm{~g}$
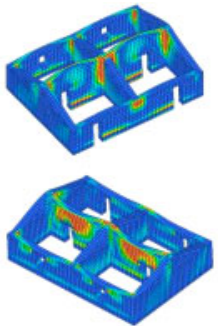

(b) $0.587 \mathrm{~g}$

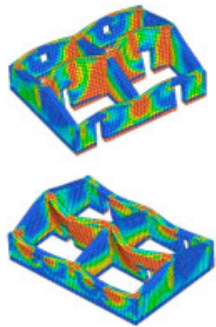

(c) $0.816 \mathrm{~g}$
Figure 7. Evolution of maximum principal strains depicted on deformed mesh for the pushover analysis in $+Y$ direction (credits: J. Ortega).
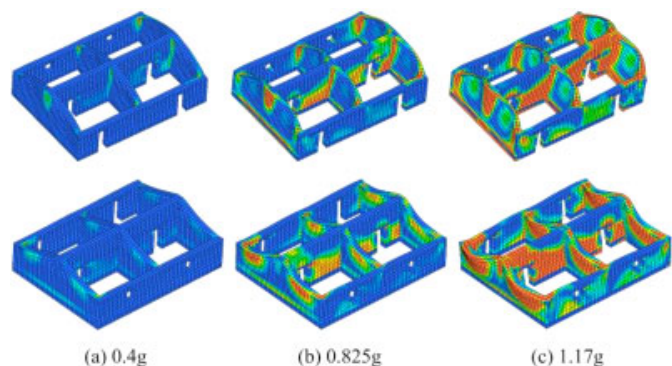

Figure 8. Evolution of maximum principal strains depicted on deformed mesh for the pushover analysis in $+\mathrm{X}$ direction (credits: J. Ortega).

Figure 6 shows the capacity curve for the reference building in both horizontal directions. The analysis shows that the structure capacity is higher than the expected for this kind of buildings, obtaining maximum load coefficients of around $0.8 \mathrm{~g}$ in $+Y$ direction and over $1.1 \mathrm{~g}$ in $+\mathrm{X}$ direction. This might be due to the small dimensions of the reference building, particularly regarding the height of the walls, and the span between walls, but mainly because the structural elements of the buildings are considered to be perfectly connected among them, avoiding their premature local out-of-plane collapse.

Figure 7 presents the evolution of the maximum principal strains, which can be used as a cracking measure in the building for the pushover analysis in $+Y$ direction. As it could be expected, the parts of the building presenting more damage are the middle walls, which should be attributed to their higher slenderness. These walls show flexural vertical cracks in the mid-span, and horizontal cracking at the base, and at the interface between the rammed earth and the stone masonry base course. The major damage takes place at the connections between perpendicular walls. The behaviour is improved by the cooperation of the orthogonal walls, which are bracing them. At the latest steps, the front and back walls also present some out-of-plane cracking and severe damage at the connections with the perpendicular walls.

The capacity in the $+\mathrm{X}$ direction is considerably higher than in the $+Y$ direction, given the bigger amount of resisting walls in this direction. Figure 8 
shows the evolution of the maximum principal strains in the building for the pushover analysis in $+X$ direction.

Again, the middle interior walls are the ones presenting more damage, but now they develop resisting mechanisms, to which in-plane damage is associated. Gable walls also show heavy flexural cracking at their mid-spans, and at the connections between perpendicular walls. Horizontal cracking at the stone base is also substantial, as well as in the connection between both, the stone masonry, and the rammed earth.

\section{NUMERICAL PARAMETRIC ANALYSIS}

As previously mentioned, the seismic vulnerability assessment for this type of vernacular constructions is a difficult task, due to the great heterogeneity, resulting from the uncertainty of many construction characteristics, such as the construction solutions and constituent materials, or different geometry configurations, often modified by previous structural or architectural interventions, among others. These construction aspects highly influence the seismic behaviour of structures and, therefore, a parametric analysis was planned, aiming at assessing this influence according to different parameters that take into account the construction particularities of the representative vernacular rammed earth construction typology, chosen as a case study. A parametric analysis will also help understanding in a more detailed way the seismic behaviour of this typology. These parameters should be identified in order to be studied, and they were selected based on knowledge of the effects of past earthquakes (Blondet et al. 2011). The observation of earthquake induced damage has traditionally been a tool for the understanding of the structural behaviour of vernacular constructions in the sequence of earthquakes. With the inspection of constructions after earthquakes, it is possible to see the adequacy or inadequacy of construction practices, and to realize which are the main parameters affecting the seismic response of constructions.

Numerical nonlinear parametric analyses were defined, in order to assess the influence of the different parameters that were considered to have a decisive influence in the seismic behaviour of selected typology, and to try to quantify it. The initial configuration of the reference model was changed in terms of geometry and construction characteristics, and new models were built according to the parameters. The comparative analysis between the new models and the reference one is made in terms of capacity curves, and intends to identify the parameters that have a bigger influence in the building seismic response.

\subsection{Plan configuration}

Most of the buildings of this type show a very regular rectangular shape, but different length to width ratios may influence the seismic response of the building. Thus, the influence of the in-plan slenderness of the building was evaluated through two numerical models,

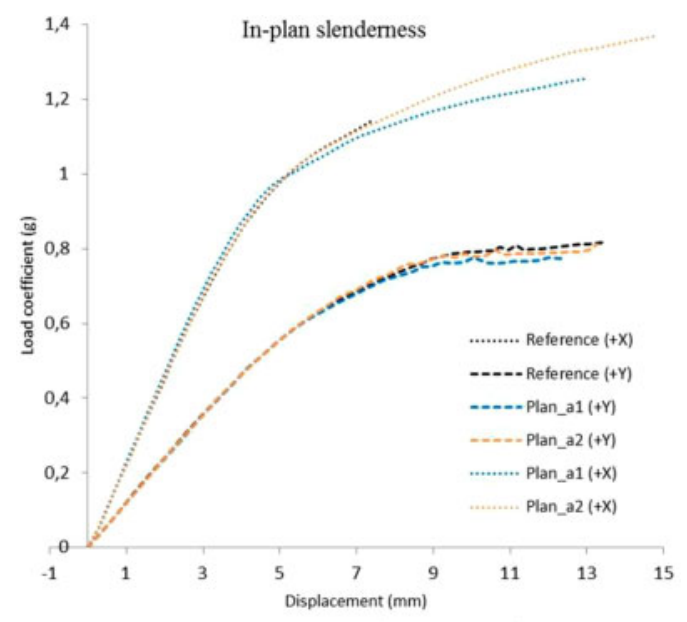

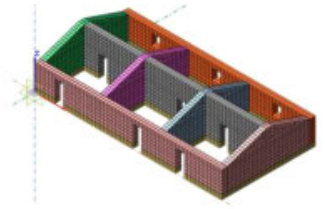

Plan_al

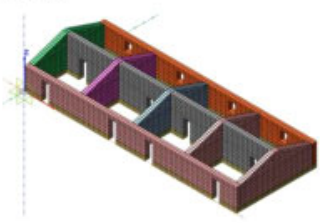

Plan_a2
Figure 9. Capacity curves and new models built for the evaluation of the influence of the in-plan slenderness (credits: J. Ortega).

namely by adding cells to the reference building to increase its slenderness. Figure 9 shows the new models and the results in terms of capacity curves, showing that this parameter has little influence on the seismic response, mainly because the resisting mechanisms do not vary.

In addition, the influence of an irregular shape configuration was evaluated, and three models were built to assess this parameter by adding cells to the reference building, so the initial rectangular plan of the building is transformed. These cells are added at both sides of the building, changing the symmetry conditions both in $\mathrm{X}$ and $\mathrm{Y}$ directions. The size of the cells is also changed in the different analyses. The idea of adding these cells resulted from inspections of several vernacular buildings, where this configuration was observed. The results in terms of capacity curves and the new models are shown in Figure 10. The capacity curves show that the building response to horizontal loading is not very sensitive to the presence of projections, unless this part presents a significant size. The biggest difference can be found in the pushover analysis in $+Y$ direction, in the analysis for the building 'Plan_b1'. In this case, the cell added is big enough to change the failure mode of the building (Fig. 11), which now takes place at the independent cell that is freer to deform and allow some torsion effects to take place. In terms of the $\mathrm{X}$ direction, buildings 'Plan_b1' and 'Plan_b2' show also a decrease in their capacity, which may be due to the bigger deformations taking place at the independent body. In every case, no significant contribution 


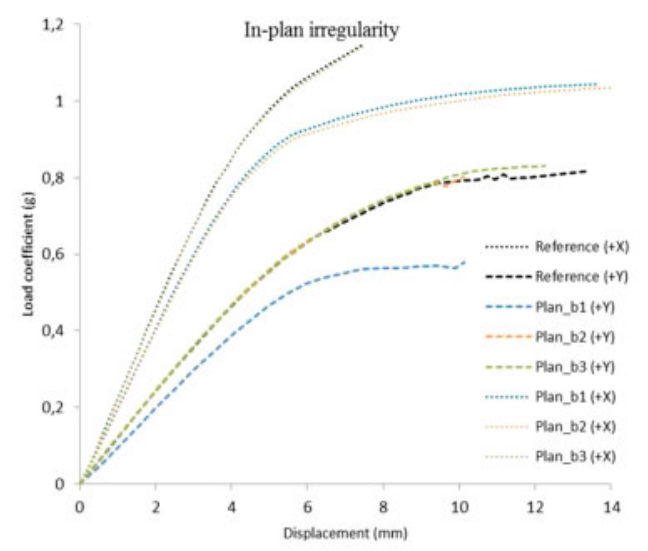

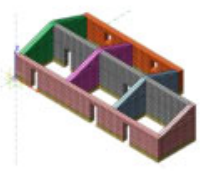

Plan_bl

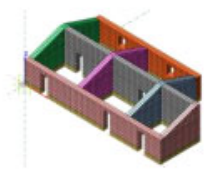

Plan_b2

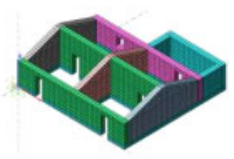

Plan_b3
Figure 10. Capacity curves and new models built for the evaluation of the influence of the in-plan irregularity (credits: J. Ortega).

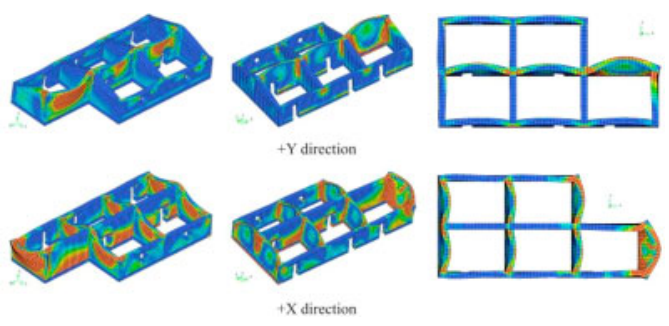

Figure 11. Maximum principal strains (a cracking measure) depicted on deformed mesh at failure for building 'Plan_b1' (credits: J. Ortega).

of a torsional response was found, resulting possibly from small dislocation of the rigidity center, in relation to the geometric center.

Another common source of plan irregularity showed by this type of buildings concerns the distribution of the resisting elements, and the lack of symmetry in one or both orthogonal directions. This may lead to an eccentricity of the stiffness centre with relation to the mass centre, enhancing the torsional effects in the event of an earthquake. Therefore, three more models were built, changing the internal distribution of the walls in relation to the reference building, in order to evaluate the influence of this stiffness eccentricity. Some interior walls were removed or added, aiming at avoiding the symmetry conditions used for the reference building, and at obtaining some eccentricity. Results in terms of capacity curves, as well as the new models constructed, are presented in Figure 12. It should be noted that for the building 'Plan_c1', only the $+Y$ pushover analysis was carried out. because

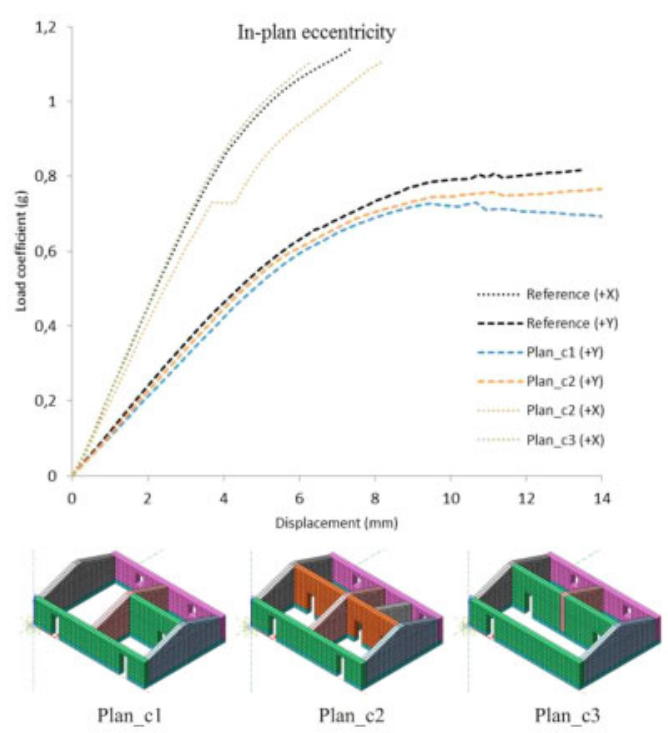

Figure 12. Capacity curves and new models built for the evaluation of the influence of the in-plan eccentricity (credits: J. Ortega).
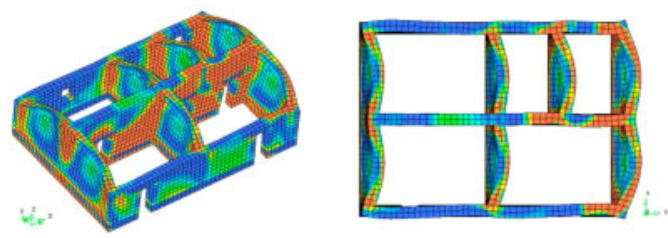

Figure 13. Maximum principal strains depicted on deformed mesh at failure for building Plan_c2 in +X direction (credits: J. Ortega).

conditions for the $+\mathrm{X}$ pushover analysis are much altered to be comparable, as one of the walls is now covering a much larger span. Similarly, regarding the building 'Plan_c3', only the pushover analysis in the $+\mathrm{X}$ direction is carried out. The analyses in the remaining directions will be performed as a next step, to assess the influence of the maximum distance between walls. Slight differences can be observed in terms of ultimate load or failure modes for both directions. A small decrease in the capacity of the buildings in the $+Y$ direction is observed, which can be ascribed to this lack of irregularity and torsional effects. In terms of the capacity of the building in the $+X$ direction, the biggest difference is observed for the building 'P2c_2', which may be due to the introduction of a new door in the wall, and the subsequent reduction of the size of the resisting piers (Fig. 13).

\subsection{Load bearing walls morphology}

The vertical resisting elements of this building typology consist of load bearing rammed earth walls. The wall thickness of this type of rammed earth buildings 


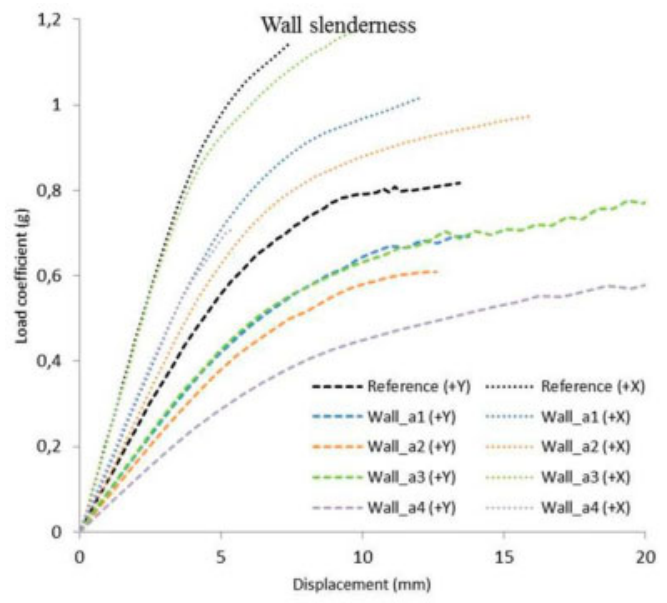

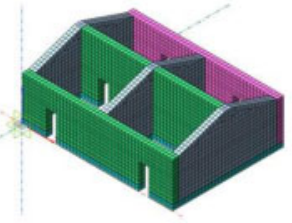

Wall_a1 / Wall_a2

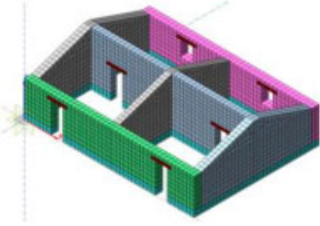

Wall_a3 / Wall_a4
Figure 14. Capacity curves and new models built for the evaluation of the influence of the wall slenderness (credits: J. Ortega).

lies between 0.45 and $0.6 \mathrm{~m}$, being most commonly $0.5 \mathrm{~m}$. The maximum height of the walls is more variable, and the most slender elements can be much more vulnerable to the seismic action. Initially, two models were built, aiming at evaluating the influence of this parameter, by increasing the height of the walls in $0.5 \mathrm{~m}$ (building 'Wall_a1'), and in $1.0 \mathrm{~m}$ ('Wall_a2'), and keeping the wall thickness the same at $0.5 \mathrm{~m}$. Secondly, another two models were built modifying the thickness of the inner walls, which are usually thinner than the exterior ones ('Wall_a3' and 'Wall_a4'). The four new models and results in terms of capacity curves are presented in figure 14 .

As expected, the seismic capacity of the building in both directions decreases when increasing the height of the walls and, consequently, by increasing the flexural damage, the damage at the connections between perpendicular walls increase, both in the internal and the external walls. In terms of the failure mode in the $+\mathrm{Y}$ direction, failure does not take place only in the middle walls and at the base course, as in the reference building. Now, the front and back walls present also substantial flexural damage, mainly flexural cracks at the mid-span and at the connections with the perpendicular walls. There is barely any horizontal cracking at the base (Fig. 15). Regarding the failure mode in the $\mathrm{X}$ direction, damage is again mostly concentrated in the rammed earth walls, while the stone base now barely suffers from any damage. The common diagonal cracking, showed by in-plane shear failure of the
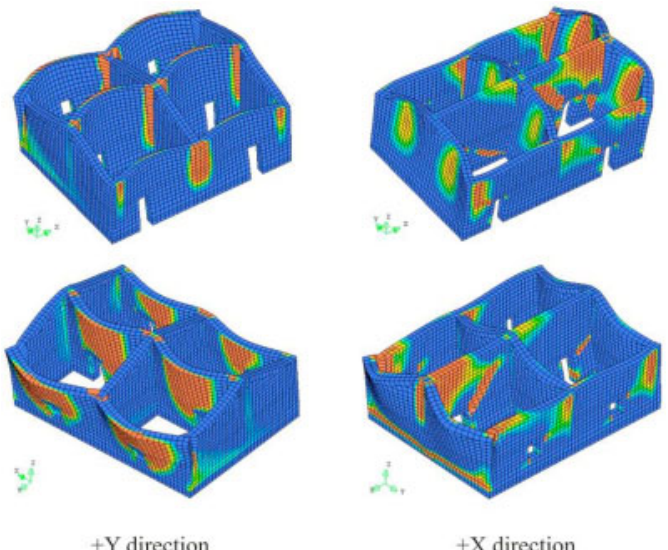

$+\mathrm{X}$ direction

Figure 15. Maximum principal strains (a cracking measure) depicted on deformed mesh at failure for building 'Wall_a1'.

walls, is more clearly developed, together with flexural damage at the connections between perpendicular walls (Fig. 15).

Four models were built aiming at evaluating the influence of the maximum free span of the walls, as the longest elements without intermediate supports can be very vulnerable to the seismic action. Two of the models were already built, in order to assess the influence of in-plane eccentricity, as previously stated. All models increase the maximum span covered by some of the rammed earth walls in the building, while keeping the wall thickness the same at $0.5 \mathrm{~m}$. Buildings 'Wall_b3' and 'Wall_b4' increase the length of the walls in the $\mathrm{X}$ direction in $0.5 \mathrm{~m}$, and $1.0 \mathrm{~m}$ respectively. The models and results in terms of capacity curves are presented in figure 16 . The capacity curves show that, as it could be expected, when the span covered by the walls is doubled, as in models 'Wall_b1' and 'Wall_b2', the capacity of the building is highly reduced. The elements get to behave practically as free standing walls, highly reducing their horizontal resisting capacity. Failure takes place in these elements, consisting of an out-of-plane failure, a combination of flexural cracking at the mid-span of the walls and substantial horizontal cracking at the base. For the models 'Wall_b3' and 'Wall_b4', there is also a reduction of the capacity of the building in the $+\mathrm{Y}$ direction, when increasing the span covered by these walls.

The out-of-plane failure, also observed in the reference building, is more evident by increasing the span. However, regarding the pushover analysis in $+\mathrm{X}$ direction, the differences are smaller, and the response to horizontal loading is very similar, even though the area of resisting walls in that direction has been increased. The base course of the wall is built in stone masonry, usually schist or granite, and it is present almost in every building of this typology (Fig. 17). They have a variable height, which can usually vary from 0.45 up to $1 \mathrm{~m}$. The influence of the stone masonry course and its height in the seismic behaviour 


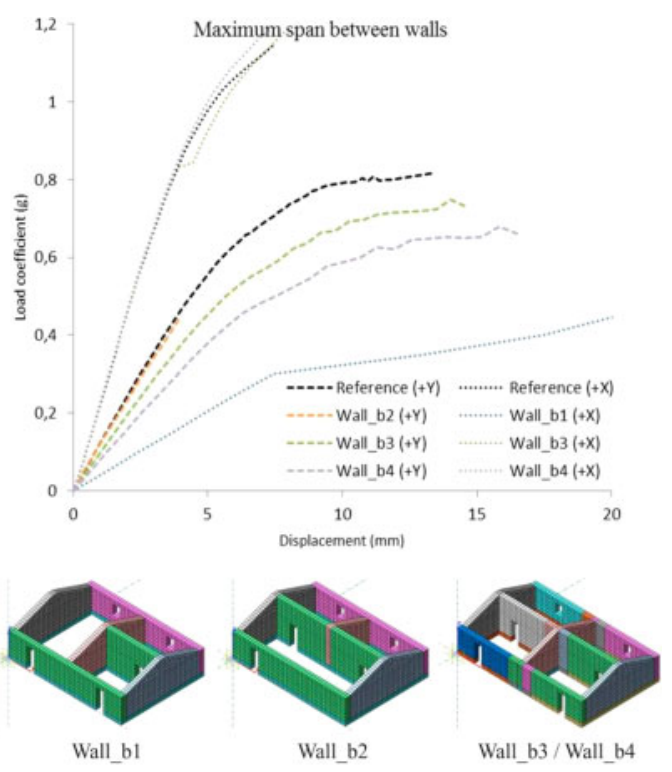

Figure 16. Capacity curves and new models built for the evaluation of the influence of the maximum span between walls (credits: J. Ortega).
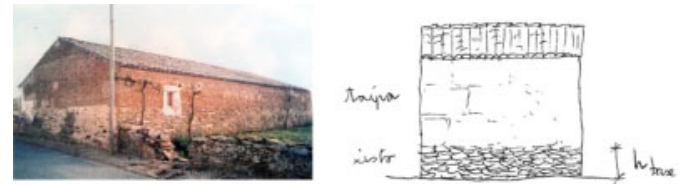

Figure 17. Stone masonry base course usually observed in this building typology (left) building in Outeiro (Correia 2007).

of the building was evaluated by constructing two different models.

First, the stone base was completely removed and the walls were considered to be built only with rammed earth. A second model was built with the stone base reaching a height of $1.0 \mathrm{~m}$. The models and the results in terms of capacity curves are presented in figure 18.

The main difference in the results consists on the variation in the stiffness of the model, mainly resulting from the difference in stiffness between both materials. When there is no stone masonry base course, the building deforms more, but there is not a remarkable difference in terms of maximum load coefficient, or failure modes (both in $+\mathrm{X}$ and $+\mathrm{Y}$ directions). Similarly, when the height of the stone base is increased, a stiffer behaviour is observed, together with an increase in the capacity of the building in the Y direction. The failure modes are very similar, but the horizontal cracking, at the stone base, is enhanced.

\subsection{Type of roofing system}

Different types of roofs can be commonly observed in these buildings (Fig. 19). The type of roof has a

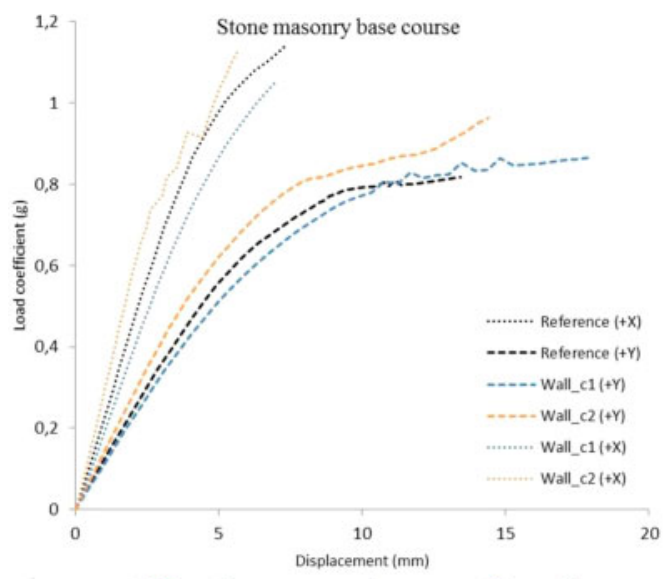

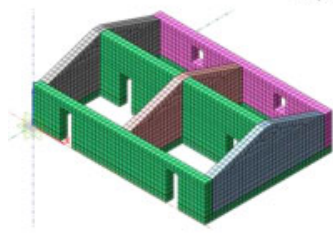

Wall_cl

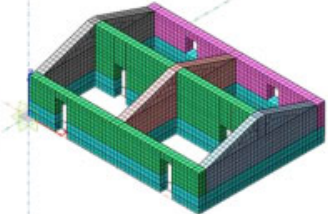

Wall_c2
Figure 18. Capacity curves and new models built for the evaluation of the influence of the stone masonry base course (credits: J. Ortega).
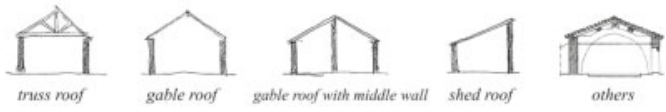

Figure 19. Types of roofing systems usually observed in this building typology (credits: J. Ortega).

decisive influence, since it modifies the geometry of the building.

The models with distinct types of roofs, and the results in terms of capacity curves, are presented in figure 20. For instance, if a truss roof is considered ('Roof_a1'), the height of the middle wall is significantly reduced to the same height as the exterior walls and, therefore, the capacity of the building may increase. On the other hand, these changes can lead to the formation of new vulnerable elements, such as the gable wall. The lack of a middle wall, bracing the gable end wall, increases the vulnerability of this element to out-of-plane loading, which becomes highly susceptible to collapse. Therefore, the seismic capacity of the building in $+X$ direction decreases significantly. If the roof is composed of rafters, without a middle wall, so they can exert a thrust on the walls ('Roof_a2'), the capacity of the building in $+Y$ direction is also highly compromised. If a middle wall is added, acting as a brace of the gable walls (third model - 'Roof_b1'), and simulating proper coupling between the parallel walls, a notable increase in the global stiffness of the model was observed in the $+Y$ direction, since the walls are able to develop resisting mechanism to the horizontal action simultaneously. However, there is no 

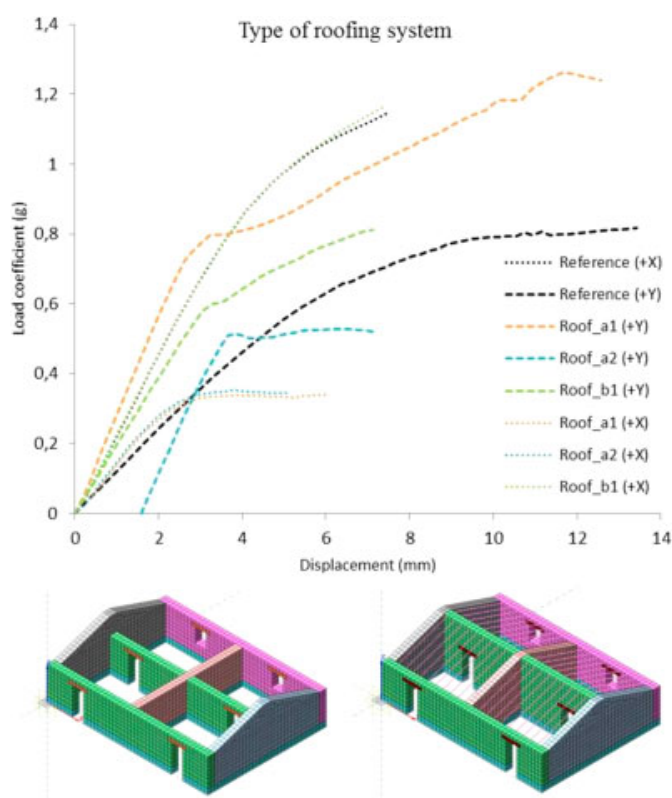

Roof_a1 / Roof_a2

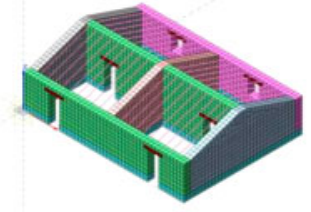

Roof_bl

Figure 20. Capacity curves and new models built for the evaluation of the influence of the type of roofing system (credits: J. Ortega).

improvement in terms of ultimate load in relation to the reference model.

\section{CONCLUSIONS}

The effect of some geometrical and construction characteristics in the seismic response of the building has been evaluated by means of a numerical parametric study, using pushover analysis, where the loading was considered to be proportional to the mass. Different parameters that were initially assumed to have a relevant influence in the seismic behaviour were selected and adjusted for the specific building typology studied. The results obtained confirm that most of the parameters selected have a relevant influence in the seismic behaviour of the building, particularly the wall slenderness, and the maximum span between walls, which show the maximum differences in terms of peak loads, and even have an influence in the failure modes. The results of the analysis of the reference building show that the building is more sensitive to out-of-plane failure, which can be expected due to the height to thickness ratio of the rammed earth walls assumed. The connections between orthogonal walls are also very vulnerable, showing big concentration of stresses. This is particularly important, given the fact that a perfect connection between the walls was assumed in this first set of analyses. This is not usually true for this type of buildings, which are many times characterised by having poor wall-to-wall connections.

\section{ACKOWLEDGEMENTS}

The authors gratefully acknowledge the support by the Portuguese Science and Technology Foundation (FCT) to the research project 'SEISMIC-V - Vernacular Seismic Culture in Portugal' (PTDC/ATP-AQI/ 3934/2012).

\section{REFERENCES}

Angulo-Ibáñez, Q., Mas-Tomas, A., Galvañ-Llopis, V. \& Montesinos, J.L. (2012). Traditional braces of earth constructions. Construction and Building Materials 30: 389-399.

Blondet, M., Villa García, M.G., Brzev, S. \& Rubiños, A. (2011). Earthquake-resistant construction of adobe buildings: A tutorial. Earthquake Engineering Research Institute.

Braga, A.M. \& Estêvão, J.M.C. (2010). Os sismos e a construção em taipa no Algarve. Sísmica 2010 - $8^{\circ}$ Congresso de Sismologia e Engenharia Sísmica. Aveiro, Portugal.

Bui, Q.B., Morel, J.C., Hans, S. \& Meunier, N. (2008). Compression behaviour of non-industrial materials in civil engineering by three scale experiments: the case of rammed earth. Materials and Structures 42(8), $1101-1116$.

Correia, M. (2005). Metodología desarrollada para la identificación en Portugal de arquitectura local sismo resistente. SismoAdobe2005, Seminario Internacional de Arquitectura, Construcción y Conservación de Edificaciones de Tierra en Áreas Sísmicas, Lima, Peru.

Correia, M. (2007). Taipa no Alentejo. Argumentum, Lisboa, Portugal.

Gallego, R. \& Arto, I. (2014). Evaluation of seismic behaviour of rammed earth structures. C. Mileto, F. Vegas, L. García-Soriano \& V. Cristini (Eds.), Vernacular Architecture: Towards a Sustainable Future. London: CRC Group.

Gomes, M.I., Lopes, M. \& Brito, J. (2011). Seismic resistance of earth construction in Portugal. Engineering Structures 33(3), 932-941.

Jaquin, P.A. (2008). Analysis of historic rammed earth constructions (PhD Thesis, Durham University, UK).

Lourenço, P.B. (2009). Recent advances in masonry structures: micromodelling and homogeneization. In U. Galvanetto \& M.H. Ferri Aliabadi (eds), Multiscale modeling in solid mechanics: computational approaches: 251-294. Imperial College Press, London, UK.

Lourenço, P.B., Mendes, N., Ramos, L.F. \& Oliveira, D.V. (2011). On the analysis of masonry structures without box behavior. International Journal of Architectural Heritage: Conservation, Analysis, and Restoration 5(4-5),369-382.

Miccoli, L., Oliveira, D.V., Silva, R., Müller, U. \& Schueremans, L. (2014). Static behaviour of rammed earth: experimental testing and finite element modelling. Materials and Structures.

Michiels, T. (2014). Seismic retrofitting techniques for historic adobe buildings. International Journal of Architectural Heritage.

NTC08 (2009). Circolare del Ministero delle Infrastrutture e dei Transporti 2 febbraio 2009, n. 617. Istruzioni per l'applicazione delle nuove norme tecniche per le costruzioni di cui al Decreto Ministeriale 14 gennaio 2008. Suppl. Ordinario n. 27 alla G.U. n. 47 del 26-022009. Italy.

TNO (2009). DIsplacement methodANAlyser (DIANA) user's manual. Release 9.4.4. Netherlands. 